\title{
THE IMPACT OF WATERSHED MORPHOMETRY ON OCCURRENCE OF TORRENTIAL FLOODS: CASE STUDY OF SERBIA AND BULGARIA
}

UDC: https://doi.org/10.18509/GBP210015p

UDC: 556.516.04:519.23(497.11+497.2)

\author{
Ana M. Petrović ${ }^{1}$, \\ Valentina Nikolova ${ }^{2}$ \\ Ivan Novković 3 \\ ${ }^{1}$ Geographical Institute „Jovan Cvijić“ of the Serbian Academy of Sciences and Arts, \\ Belgrade, Serbia \\ ${ }^{2}$ Faculty of Geoexploration, University of Mining and Geology „St. Ivan Rilski“, \\ Sofia, Bulgaria \\ ${ }^{3}$ Faculty of Geography, University of Belgrade, Belgrade, Serbia
}

\begin{abstract}
In the present study, 43 watersheds in Serbia and Bulgaria are taken for the morphometric analysis using digital elevation model in the environment of geographical information system. Statistical analysis, including correlation, regression and factor analysis is conducted with the following results and conclusions: (1) as evidenced in the correlation matrix, there is a high correlation between maximal discharges and watershed area, primarily and watershed length, secondarily; (2) the high correlation is found between independent variables watershed area and watershed length, as well as Melton index and relief ratio; (3) the multiple linear regression model encompassing all seven independent variables is obtaind with $\mathrm{R}$ squared of 70,99 , indicating that the model as fitted to that extent explains the variability in maximal discharge, and adjusted $R$ squared of 0,65 . An additional multiple regression analysis is done excluding the watershed area, due to a high starting impact on the dependent variable. In this case, a multiple regression linear model is obtained with $\mathrm{R}$ squared $=60,116$ and adjusted $\mathrm{R}$ squared $=0,53468$, leading to the conclusion that the excluded parameter has a high influence which is also confirmed by the results in correlation matrix; (4) according to the rotated component matrix in principal component analysis, first component is mostly influenced by the relief ratio, Melton index and watershed length, while the second component is determined by parameters of relief characteristics, slope $>25^{\circ}$ and watershed relief. Having regard to the results of correlation and factor analyses the watersheds are prioritized on the basis of the morphometric parameters with a purpose to indicate the watersheds with the high priority for implementation of measures reducing the flood risks. Though morphometric study itself is not sufficient to explain extensively the occurrence of maximal discharges in the events of demolishing torrential floods, morphometric analysis may meaningfully contribute to the flood risk assessment.
\end{abstract}

Keywords: morphometry, watershed, Bulgaria, Serbia

\section{INTRODUCTION}

Watershed is a basic unit for the flood hazard evaluation. Initial watershed observation comprizes the calculation of its parameters and indices and their interpretation to explain to which rate is watershed prone to flooding. Morphometrical analysis is a starting point in each hydrological study of watershed and has a wide use in specific studies such as 
flood hazard assessment. From the definition of torrential watersheds - an area with steep slopes in hilly-mountainous regions with high erosion intensity and high risk of torrential floods in the case of intensive rainfall events [1], [2] - it can be concluded how important is the morphometric analysis of these watersheds.

Watershed characteristics have a strong impact on the dependence of the runoff on rainfall in the watershed. Morphometric parameters quantitatively express geomorphology of a watershed which controls hydrological response of a watershed in the case of extreme rainfall episode. In the case of the large river basins (such as the Danube river basin) it is generally known that floods in higher parts occurr abruptly on the one hand and much slower in lower parts of the basin on the other hand. Also, the round shaped watersheds experience the floods with higher peaks of maximal discharges and shorter duration in comparisson with the elongated watersheds. Watershed management professionals especially rely on the morphometry in the case of the ungauged watersheds. Morphometric analysis defining the parameters and indices can be of high importance in an explanation of a specific torrential flood event in ungauged watersheds.

There have been many studies across the globe focusing on morphometric parameters of watersheds as static factors of torrential flood occurrence [3], [4], [5], [6], [7]. Melton [8], [9] found significant correlations by exploring the relations among morphometric properties of the relief in the analysis of watersheds in Arizona, Utah, Colorado and New Mexico. In this research, it was found that maximum valley-side slopes are correlated positively with relative relief and ruggedness number; slopes are negatively correlated with channel frequency and drainage density.

Benson (1964) [10] found in the investigation of factors of the flood occurrence in the western Gulf of Mexico basin within the United States, that watershed area and main channel length are the most important variable according to the correlation matrix of the mean annual discharge (2,33-year peak) and the independent variables. Patton and Baker (1976) [11] found in their research of watersheds in different climate and hydrological conditions of the USA-Central Texas, North Central Utah, Southern California, Indiana and Appalachian Plateau, that watershed relief and drainage density are two distinguishing factors of flash flood occurrence among morphometric parameters (when excluding the watershed area and length). Therefore, the authors suggested that extremely dissected high relief drainage basins have high flood potentials even in the case of relatively low rainfall episode. Taha et al. (2017) [12] determined the flash flood hazard for Wadi Qena (Eastern Egypt) using remote sensing and GIS techniques for calculation of the geo-morphometric indices.

Khurana et al. (2020) [13] discussed the hydrologic response of a Himalayan watershed and its sub-watersheds using various morphological parameters extracted on the base of digital elevation model employing GIS techniques, and accordingly, conducted the subwatershed prioritization. Loczy et al. (2009) [14] assessed the local flood hazard as moderate to high on the base of the analysis of channel morphometry and its evolution along the studied section of the Tisza River.

The main objective of this research is to analyse the morphometric conditions of the watersheds as a prerequisite for torrential floods occurrence and to find a relation between morphometry and maximal discharges in the events of torrential floods.

\section{STUDIED WATERSHEDS}

Study area encompasses 43 watersheds in total: 28 watersheds in Serbia, south of the Danube and the Sava River (belonging to the Drina, Kolubara, Velika Morava and 
Danube River Basins) and 15 watersheds in Bulgaria (belonging to Arda, Iskar, Vit and Yantra River Basins, while several rivers flow directly into the Black Sea), Figure 1. These watersheds are selected also in accordance with availability of data and they are all situated in hilly-mountainous and mainly rural regions. The climate of Central Serbia (south of the Danube and the Sava River) and in some of the investigated watersheds in Bulgaria is moderate-continental, while the watersheds in the southern part of Bulgaria and along the Black Sea have transitional Mediterranean climate. The average annual precipitations ranging from 650 to $1000 \mathrm{~mm}$ in higher regions.

An extreme torrential flood event is related to each studied watershed. Most of the presented torrential flood events happened in May and June which is a peak of their occurrence in Serbia and in the northern part of Bulgaria. For instance, Asparuhovo-West and Asparuhovo-East (Bulgaria) are gullies, but the sites where severe torrential flood happened on the 19-20th June 2014 taking 13 human lives. After rainy April and first half of May 2014, a tree-day rainfall episode (May 14, 15 and 16) with $428 \mathrm{~mm}$ or ca. half of total annual precipitation caused an extreme event of torrential floods of three local torrents (Čađavica, Kržava and Brštica in Serbia) which attacked municipality of Krupanj and surrounding settlements, causing the death of 2 people and material damage estimated to more than 30 million $€$.

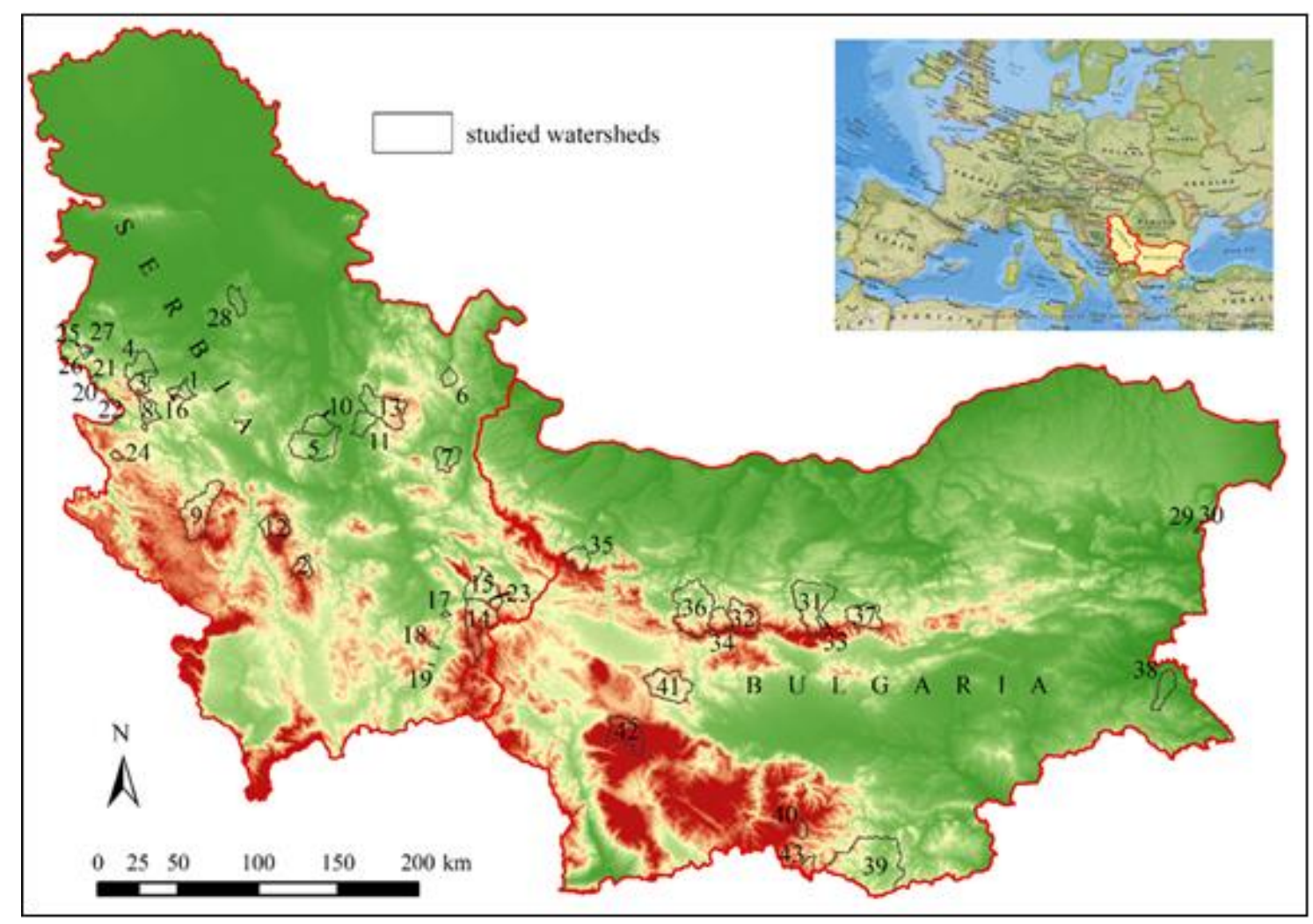

Figure 1. Map of watersheds in Serbia and Bulgaria

(the numbers of the watersheds correspond to those in Table 2)

\section{METHODS AND DATA}

Data for this work are analyzed in GIS environment on the base of 30m Shuttle Radar Topography Mission Digital Elevation Model (SRTM DEM), NASA JPL [15]. Georeferenced topographic maps with a scale of 1:25000 (10 meter contour interval) are also used since the stream map derived from the DEM had to be checked and improved. 
These data are processed in ArcGIS and QGIS. The ArcGIS and QGIS tools are used to determine the watersheds and to delineate stream lines. The slope surfaces are generated and classified. Basic morphometric parameters are calculated in ArcGIS: watershed area, watershed length, total stream length, maximal and minimal elevation points ( $\mathrm{H}$ and $\mathrm{h}$ ), and area with slope $>25^{\circ}$. Morphometric indices are computed based on the literature definitions and formulas (Table 1).

Watershed area is the first mophometric parameter which is analyzed. The size of watershed area causes the variability of the hydro-climatic and geomorphic conditions, particularly affecting a total amount of the surface runoff on slopes and consequently the maximal discharges of the streams. Watershed length is measured along the long axis of the watershed from the mouth/profile of the river to the watershed boundary.

Watershed relief is the vertical elevation distance between the highest point in the watershed and the mouth of the river or profile indicating the geodynamics of the area and development of the erosion processes [8]. Relief ratio is a measure of the general steepness of the watershed which is calculated by dividing the watershed relief with the watershed length [16], [17].

Table 1. Quantitative morphometric parameters.

\begin{tabular}{llll}
\hline $\begin{array}{l}\text { Morphometric } \\
\text { parameter }\end{array}$ & $\begin{array}{l}\text { Description } \\
\text { Formula }\end{array}$ & Units & Reference \\
\hline Watershed Area & $\mathrm{A}$ & $\mathrm{km}^{2}$ & \\
$\begin{array}{l}\text { Watershed Length } \\
\text { Watershed Relief }\end{array}$ & $\mathrm{L}$ & $\mathrm{km}$ & \\
Relief Ratio & $\mathrm{Rr}=\frac{R}{L}$ & $\mathrm{~km}$ & $\begin{array}{l}\text { Schumm 1956; Strahler } \\
\text { Mm }\end{array}$ \\
Melton Index & $M=\frac{R}{\sqrt{A}}$ & & $\begin{array}{l}\text { Melton 1957; Melton } \\
\text { Drainage Density }\end{array}$ \\
& $D=\frac{L_{t}}{A}$ & $\mathrm{~km} \cdot \mathrm{km}^{-2}$ & 1958 \\
${\text { A }>25^{\circ}}$ & $\mathrm{S}>25^{\circ}$ & $\%$ & \\
\hline
\end{tabular}

Melton index as an indicator for the ruggedness, is calculated by dividing the watershed relief by the square root of the watershed area, which is widely used in the Asian and USA literature as an indicator for erosion and debris floods, and for the identification of watersheds prone to flooding. Drainage density is the total length of streams of all orders in the watershed divided by the watershed area. This is also an indicator of the development of erosional processes, which can lead to changes in the sediment transport and to increase the solid discharge, and thus increase the disposition for floods. Watershed area with a slope $>25^{\circ}\left(\mathrm{AS}>25^{\circ}\right)$ is a topographic surface sloped $>25^{\circ}$ expressed in $\%$ of the total area of the watershed. These are the areas with higher energy of mass movement and they affect the velocity of water flow and the development of erosion processes.

The data for maximal discharges are obtained from the Hydrological yearbooks of Republic Hydrometeorological Service of Serbia and National Institute of Meteorology and Hydrology of the Bulgarian Academy of Sciences as well as from Preliminary Assessment of Flood Risk (Danube River Basin Directorate and East Aegean River Basin Directorate, Bulgaria).

In analysis of derived data on watersheds we conducted statistical analyses by using the statistical software programs - Statgraphics and SPSS version 19. For determination of the correlation between two or more variables, simple and multiple regression analyses are employed. Simple regression indicates the strength of linear regression including two 
variables $(\mathrm{Y}=\mathrm{a}+\mathrm{b} \cdot \mathrm{X})$. Multiple regression analysis, as an extension of simple regression, explores the relationship between dependent variable and two and more independent variables.

Factor analysis is a multi-variance technique with an aim to determine the extent to which shared variance exists between variables [18]. This technique has been used in two contexts in data analytics: as confirmatory, designed to confirm or negate the hypothesized structure, or exploratory, to discover a structure [19]. In factor analysis, extraction method used is principal component analysis and rotation method is varimax with Kaiser normalization. Varimax rotation includes a mathematical algorithm maximizing the high and low value factor loadings and minimizing mid value factor loadings [20]. As defined in Tabachnick and Fidell [21], principal components analysis explores the correlations among the variables to develop a few set of components summarizing empirically the correlations among the variables.

Having regard to the results of correlation and factor analyses the watersheds are prioritized in terms of torrential flood risks. The prioritization in this research is done on the basis of the morphometric parameters, following the common methodology of ranking the watersheds and expert knowledge presented in many publications [22], [23], [24].

The aim of the prioritization is to indicate the watersheds with the high priority for implementation of measures reducing the flood risks. For this purpose, each morphometric parameter is ranked taking into account its relation to the maximal discharge. In case of positive correlation, the highest rank is assigned to the watershed with the highest value of the considered morphometric parameter, and if the correlation is negative, the watershed with the lowest value of the given morphometric parameter is evaluated with the highest rank.

The compound priority number of each watershed is calculated as an average of the priority numbers of the morphometric parameters. On the basis of the compound priority the watersheds are divided into three groups - high, moderate and low priority. As limit values we accepted $25 \%$ deviation from the average value of the compound priority numbers.

\section{RESULTS}

Output of morphometric analysis for studied watersheds is given in Table 2. Watershed areas ranges from $0,5 \mathrm{~km} 2$ to $1155 \mathrm{~km} 2$. Watershed lengths varies from $1,4 \mathrm{~km}$ to $85 \mathrm{~km}$ and watershed relief from 0,2 to $2,2 \mathrm{~km}$. Relief ratio is in the range from 0,014 to 0,185 and values of Melton index from 0,03 to 0,45. 


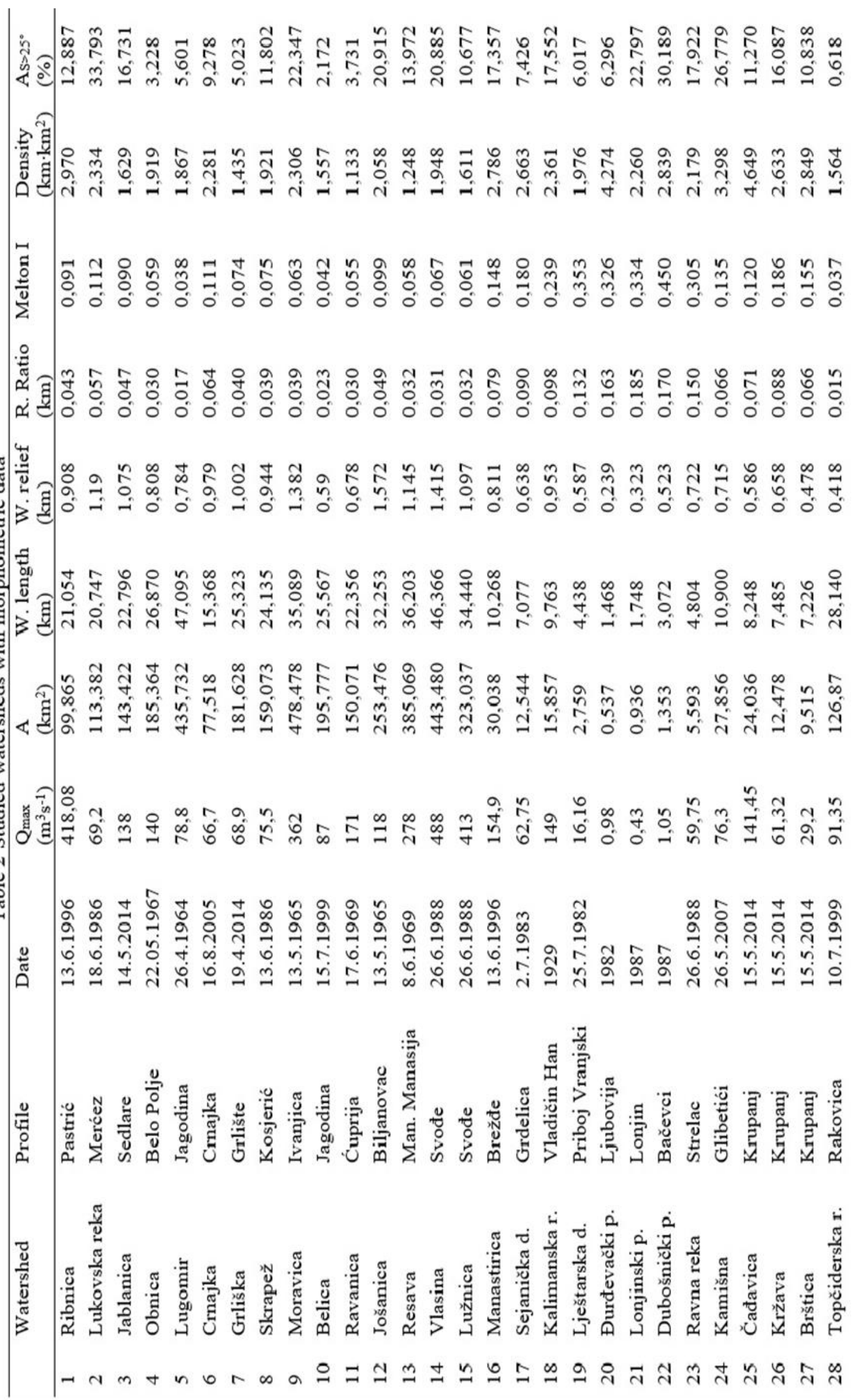




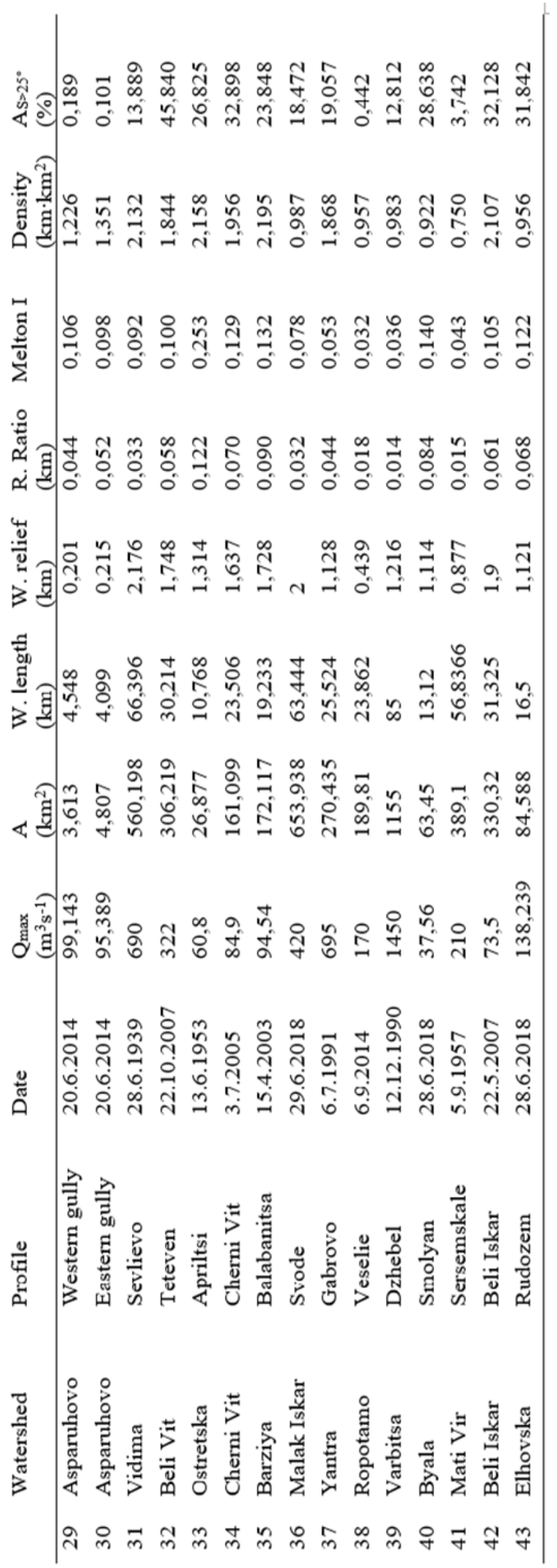


Most of the watersheds have a value of Melton ruggedness number lower than 0,3, indicating higher susceptibility to torrential floods with low amount of the sediment transport, while watersheds with higher Melton index than 0,3 are prone to debris flow processes [25]. Drainage density varies from 0,75 to $4,6 \mathrm{~km} / \mathrm{km} 2$. Areas with slope $>25^{\circ}$ in watersheds varies from 0,1 to $45,8 \%$. Watersheds with an area less than $100 \mathrm{~km} 2$ have the lower watershed relief and watershed length and the higher relief ratio, Melton index and stream density, in comparison with larger watersheds. Measured maximal discharges varies from $0,4 \mathrm{~km} 3 \mathrm{~s}-1$ to $1450 \mathrm{~m} 3 \mathrm{~s}-1$.

Before taking into account all envisaged parameters for the multiple regression analysis, the correlation between dependent variable - maximal discharges and the first independent parameter - watershed areas is explored. The output shows fitting a linear model to describe the relationship between variables. Since the P-value in the ANOVA table is less than 0,01 , there is a statistically significant relationship between variables at the $99 \%$ confidence level. The determination coefficient indicates that the model as fitted explains $68,257 \%$ of the variability in dependent variable. The Pearson correlation coefficient equals 0,83 and nonparametric Spearman Rho is 0,72, indicating a moderately strong relationship between the variables. This is a reasonable finding since the quantity of water discharged to the stream is mainly proportional to the watershed area.

By adding another parameter from the list-watershed length, a turn to a multiple linear regression model is required. In this step, the determination coefficient is slightly higher, indicating that the model as fitted with two independent variables explains $69,87 \%$ of the variability in dependent variable and the adjusted $\mathrm{R}$ squared is $0,684 \%$ (Table 3 ). Including the watershed relief as the third dependent variable, multiple regression analysis gives the determination coefficient of 70,306, while adjusted $\mathrm{R}$ squared is getting slightly lower and this trend of decrease continues by adding all other variables

Table 3. Outputs of multiple regression analysis.

\begin{tabular}{|l|l|l|l|}
\hline $\mathrm{Q}$ & $\mathrm{R}^{2}$ & $\mathrm{R}^{2}$ (adjusted for d.f.) & Standard error \\
\hline A, L & 69,873 & 68,367 & 0,562 \\
\hline A, L, R & 70,306 & 68,022 & 0,565 \\
\hline A, L, R, Rr & 70,317 & 67,193 & 0,572 \\
\hline A, L, R, Rr, M & 70,325 & 66,315 & 0,580 \\
\hline A, L, R, Rr, M, D & 70,931 & 66,087 & 0,582 \\
\hline A, L, R, Rr, M, D, S & 70,987 & 65,184 & 0,590 \\
\hline
\end{tabular}

Next multiple regression models include relief ratio as the fourth independent variable and then Melton index as the fifth variable, indicating there is almost no changes of the determination coefficient value. When multiple linear regression model encompassed the sixth constant-drainage density, it resulted in slightly higher determination coefficient that increased at first decimal-70,931. By adding the last morphometric parameters, area with slope $>25^{\circ}$, the final multiple linear regression model is obtained with $\mathrm{R}$ squared $=70,99$, indicating that the model as fitted to that extent explains the variability in maximal discharge and adjusted $\mathrm{R}$ squared $=0,65184$, which points out that graduated adding of parameters did not have a greater impact on the variability of the dependent variable. The equation of the fitted model is as follows:

$$
\begin{gathered}
\mathrm{Qmax}=1,279 \mathrm{E}-10+1,221 \cdot \mathrm{A}-0,344 \cdot \mathrm{L}-0,113 \cdot \mathrm{R}-0,103 \cdot \mathrm{Rr}+ \\
0,046 \cdot \mathrm{M}+0,093 \cdot \mathrm{D}+0,04 \cdot A_{S>25^{\circ}}
\end{gathered}
$$


An additional multiple regression analysis is done excluding the watershed area, given that there was a high starting impact on the dependent variable. In this case, a multiple regression linear model is obtained with $\mathrm{R}$ squared $=60,116$ and adjusted $\mathrm{R}$ squared $=0,53468$, leading to the conclusion that the excluded parameter has a high influence which is also confirmed by the results in correlation matrix. Including the watershed area as the independent variable reduces the standard error-from 0,682 to 0,582 . There is a statistically significant relationships between the variables at the $99 \%$ confidence level in all steps of the multiple regression analyses, since the P-value in the analysis of variance (ANOVA) is less than 0,01 .

In the matrix of correlations (Table 4) between all observed variables, there is a high correlation between maximal discharges and watershed area, primarily and watershed length, secondarily. The high positive correlation is also found between independent variables watershed area and watershed length, as well as Melton index and relief ratio. There is also a negative correlation $>-0.6$ between watershed length and relief ratio and Melton index, respectively.

Table 4. Correlation matrix.I

\begin{tabular}{lllllllll}
\hline & $\mathrm{A}$ & $\mathrm{L}$ & $\mathrm{R}$ & $\mathrm{Rr}$ & $\mathrm{M}$ & $\mathrm{D}$ & $\mathrm{A}_{S>25^{\circ}}$ & $\mathrm{Q}_{\max }$ \\
\hline $\mathrm{A}$ & 1 & & & & & & & \\
$\mathrm{~L}$ & 0,9538 & 1 & & & & & & \\
$\mathrm{R}$ & 0,5611 & 0,5992 & 1 & & & & & \\
$\mathrm{Rr}$ & $-0,5628$ & $-0,6665$ & $-0,2697$ & 1 & & & & \\
$\mathrm{M}$ & $-0,5226$ & $-0,6097$ & $-0,2959$ & 0,9623 & 1 & & & \\
$\mathrm{D}$ & $-0,4165$ & $-0,4638$ & $-0,2052$ & 0,4953 & 0,4617 & 1 & & \\
$\mathrm{~A}_{\mathrm{S}>25^{\circ}}$ & 0,0236 & $-0,0301$ & 0,5806 & 0,3167 & 0,2469 & 0,1250 & 1 & \\
$\mathrm{Q}_{\max }$ & 0,8262 & 0,7498 & 0,3839 & $-0,4286$ & $-0,3962$ & $-0,2585$ & 0,0026 & 1 \\
\hline
\end{tabular}

After simple and multiple regression analysis, the factor analysis using the prinicipal component method (PCA) was performed. Feasibility of factor analysis is defined by two tests - Kaiser-Meyer-Olkin (KMO) Measure of Sampling Adequacy [26] (Kaiser 1974) and Bartlett's Test of Sphericity [27] (Bartlett 1954). According to the KMO test (Table $5)$, there is a sense to conduct factor analysis with this dataset, since the value of 0,636 exceeds the recommended value acceptable for a good factor analysis $(0,6$ and 0,5 according to different authors). Bartlett's test with value of $\mathrm{p}<0,05$ justifies the application of the factor analysis and indicates the factorability of the correlation matrix.

Table 5. KMO and Bartlett's Test.

\begin{tabular}{|l|l|l|}
\hline Kaiser-Meyer-Olkin Measure of Sampling Adequacy & 0,636 \\
\hline \multirow{3}{*}{ Bartlett's Test of Sphericity } & Approx. Chi-Square & 299,839 \\
\cline { 2 - 3 } & df & 21 \\
\cline { 2 - 3 } & Sig. & 0,000 \\
\hline
\end{tabular}

Factor analysis (method: Principal components) extracted two components with the characteristic value of $\geq 1$ according to the Kaiser criterion. Also, the screeplot reveals the existence of a clear breaking point behind the second point (Figure 2). The contribution of the first component is 53,844 , while the contribution of the second component is 24,335 , so that both have cumulative $\%$ of 78,179 , which means that these two components together explain over $78 \%$ variance. 


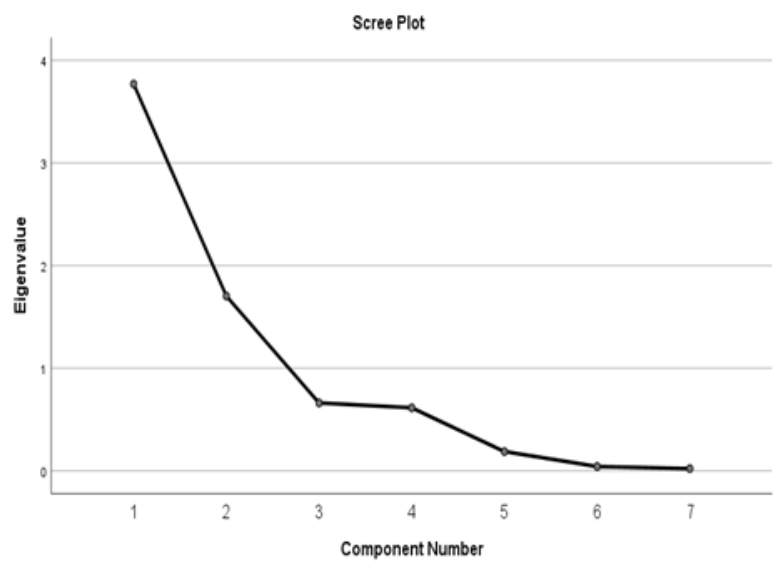

Table 6. Rotated Component Matrix

Figure 2. Scree plot from factor analysis

After rotation converged in 3 iterations, a rotated component matrix is derived. According to the values of loadings (Table 6), first component is mostly influenced by the relief ratio and Melton index with positive loadings and watershed length and watershed area with negative loadings, while the second component is determined by slope $>25^{\circ}$ and watershed relief, both with positive loadings. Here are two logical findings: (1)

According to the first component, the smaller watershed area and length, the higher relief ratio and Melton index. However, relief ratio is a morphometric index calculated using the parameter of watershed length and Melton index is calculated using the parameter of watershed area in the equations. (2) As defined in the second component, the higher the relief ratio, the higher area under slope $>25^{\circ}$. Watershed area and watershed length belong to the watershed geometry, while drainage density is a parameter of the drainage characteristics and watershed relief, relief ratio, Melton index and slope $>25^{\circ}$ belong to the relief characteristics.

On the basis of the analyses of the morphometric parameters and their relation to the maximal discharge the prioritization of the watersheds in terms of flood risk is conducted (Table 7). We excluded the parameter of slope (area with slope $>25^{\circ}$ ) due to a low correlation with the maximal discharge as in correlation matrix. Watersheds with a compound priority value deviated by more than $25 \%$ from the average value of the compound priority series are evaluated as watersheds with high priority, where the flood risk measures need to be taken first. Watersheds where the value of the compound priority deviates less than $25 \%$ of the average value are included in the group of low priority and the others are sorted in the group of moderate priority.

The watersheds with high priority have mostly an area larger than $150 \mathrm{~km} 2$ and length from 22,36 to $85 \mathrm{~km}$ (only one of the watersheds in this group have an area less than 150 $\mathrm{km} 2$ - Topčiderska river). In the group of moderate priority dominate watersheds with the area less than $150 \mathrm{~km} 2$ and the watersheds length varying between 13,12 and 24,14 km. Three of the watersheds with moderate priority have an area between 159 and $172 \mathrm{~km} 2$. Their presence in this group could be explained with the relatively high values of the relief ratio $(0,07-0,09)$ and the drainage density $(1,92-2,19)$. The third group of priority (low priority) includes the watersheds with an area between 0,54 and 30,04 km2 and the length less than $11 \mathrm{~km}$.

However, from the flood susceptibility point of view, watersheds from the third group of priority could be the highest priority watersheds, especially when considering the extreme maximal discharges and watershed area. Although torrential floods are complex phenomena, this morphometric prioritization could support the planning process and 
mitigating the flood risk, and can be considered as a first stage of more complex prioritization by adding other parameters, such as hydro-climatic and infrastructural.

Table 7. Watershed prioritization

\begin{tabular}{|c|c|c|c|c|c|c|c|c|c|}
\hline \multirow[t]{2}{*}{ Watershed } & \multirow[t]{2}{*}{ Profil } & \multicolumn{6}{|c|}{ Watersheds priority numbers according to: } & \multirow{2}{*}{$\begin{array}{l}\text { Comp. } \\
\text { numbe } \\
\mathrm{r}\end{array}$} & \multirow[b]{2}{*}{ 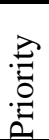 } \\
\hline & & $\begin{array}{l}\text { Are } \\
\text { a }\end{array}$ & $\begin{array}{l}\text { Lengt } \\
\mathrm{h}\end{array}$ & $\begin{array}{l}\text { Relie } \\
\text { f }\end{array}$ & $\begin{array}{l}\text { Relie } \\
\text { f ratio }\end{array}$ & $\begin{array}{l}\text { Melton } \\
\text { index }\end{array}$ & $\begin{array}{l}\text { Drainag } \\
\text { e density }\end{array}$ & & \\
\hline Varbitsa & Dzhebel & 43 & 43 & 33 & 30 & 42 & 39 & 38,33 & \\
\hline Malak Iskar & Svode & 42 & 41 & 42 & 28 & 28 & 38 & 36,50 & \\
\hline Mati Vir & Sersemskale & 37 & 40 & 20 & 34 & 38 & 43 & 35,33 & \\
\hline Resava & M, Manasija & 36 & 37 & 31 & 28 & 35 & 35 & 33,67 & \\
\hline Vidima & Sevlievo & 41 & 42 & 43 & 27 & 25 & 18 & 32,67 & \\
\hline Vlasina & Svođe & 39 & 38 & 36 & 29 & 31 & 23 & 32,67 & \\
\hline Lugomir & Jagodina & 38 & 39 & 17 & 33 & 40 & 27 & 32,33 & \\
\hline Lužnica & Svođe & 34 & 35 & 27 & 28 & 33 & 30 & 31,17 & \\
\hline Moravica & Ivanjica & 40 & 36 & 35 & 26 & 32 & 12 & 30,17 & \\
\hline Yantra & Gabrovo & 32 & 28 & 30 & 23 & 37 & 26 & 29,33 & \\
\hline Ropotamo & Veselie & 29 & 25 & 6 & 32 & 43 & 40 & 29,17 & \\
\hline Beli Vit & Teteven & 33 & 32 & 40 & 18 & 22 & 28 & 28,83 & \\
\hline Belica & Jagodina & 30 & 29 & 11 & 31 & 39 & 32 & 28,67 & \\
\hline Grliška & Grlište & 27 & 27 & 25 & 25 & 30 & 33 & 27,83 & \\
\hline Beli Iskar & Beli Iskar & 35 & 33 & 41 & 17 & 21 & 19 & 27,67 & \\
\hline Jošanica & Biljanovac & 31 & 34 & 37 & 21 & 23 & 20 & 27,67 & \\
\hline Obnica & Belo Polje & 28 & 30 & 18 & 30 & 34 & 25 & 27,50 & \\
\hline Topčiderska r. & Rakovica & 21 & 31 & 5 & 34 & 41 & 31 & 27,17 & $\frac{\pi}{60}$ \\
\hline Ravanica & Ćuprija & 23 & 22 & 14 & 30 & 36 & 37 & 27,00 & 琵 \\
\hline Skrapež & Kosjerić & 24 & 26 & 22 & 26 & 29 & 24 & 25,17 & \\
\hline Jablanica & Sedlare & 22 & 23 & 26 & 22 & 27 & 29 & 24,83 & \\
\hline Cherni Vit & Cherni Vit & 25 & 24 & 38 & 13 & 15 & 22 & 22,83 & \\
\hline Elhovska & Rudozem & 18 & 18 & 29 & 14 & 16 & 41 & 22,67 & \\
\hline Byala & Smolyan & 16 & 16 & 28 & 10 & 12 & 42 & 20,67 & \\
\hline Barziya & Balabanitsa & 26 & 19 & 39 & 8 & 14 & 15 & 20,17 & \\
\hline Lukovska r. & Merćez & 20 & 20 & 32 & 19 & 18 & 11 & 20,00 & 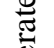 \\
\hline Ribnica & Pastrić & 19 & 21 & 21 & 24 & 26 & 4 & 19,17 & $\overline{\bar{v}}$ \\
\hline Crnajka & Crnajka & 17 & 17 & 24 & 16 & 19 & 13 & 17,67 & $\stackrel{0}{\Sigma}$ \\
\hline Asparuhovo & Western g. & 5 & 6 & 1 & 23 & 20 & 36 & 15,17 & \\
\hline Asparuhovo & Eastern g. & 6 & 4 & 2 & 20 & 24 & 34 & 15,00 & \\
\hline Ostretska & Apriltsi & 13 & 14 & 34 & 6 & 6 & 17 & 15,00 & \\
\hline Manastirica & Brežđe & 15 & 13 & 19 & 11 & 11 & 7 & 12,67 & \\
\hline Kamišna & Glibetići & 14 & 15 & 15 & 15 & 13 & 3 & 12,50 & \\
\hline Kalimanska r. & Vladičin H. & 11 & 12 & 23 & 7 & 7 & 10 & 11,67 & \\
\hline Čađavica & Krupanj & 12 & 11 & 9 & 12 & 17 & 1 & 10,33 & \\
\hline Kržava & Krupanj & 9 & 10 & 13 & 9 & 8 & 9 & 9,67 & \\
\hline Sejanička d. & Grdelica & 10 & 8 & 12 & 8 & 9 & 8 & 9,17 & \\
\hline Ravna reka & Strelac & 7 & 7 & 16 & 4 & 5 & 16 & 9,17 & \\
\hline Brštica & Krupanj & 8 & 9 & 7 & 15 & 10 & 5 & 9,00 & \\
\hline Lještarska d. & Priboj V. & 4 & 5 & 10 & 5 & 2 & 21 & 7,83 & \\
\hline Lonjinski p. & Lonjin & 2 & 2 & 4 & 1 & 3 & 14 & 4,33 & \\
\hline Dubošnički p. & Bačevci & 3 & 3 & 8 & 2 & 1 & 6 & 3,83 & 3 \\
\hline Đurđevački p. & Ljubovija & 1 & 1 & 3 & 3 & 4 & 2 & 2,33 & ـ \\
\hline
\end{tabular}

\section{CONCLUSION}

In this paper, morphometric analysis for 43 watersheds in Serbia and Bulgaria with related maximal discharges in the events of torrential floods is conducted followed by the statistical analyses which gave satisfactory results. The high correlation between maximal 
discharges and watershed area is found. A multiple linear regression model including all seven independent variables is obtained with $\mathrm{R}$ squared $=70,99$, indicating that the model as fitted to that extent explains the variability in maximal discharge and adjusted $\mathrm{R}$ squared is 0,65184. Factor analysis (method: Principal components) extracts two components in rotated correlation matrix with the characteristic value of $\geq 1$ according to the Kaiser criterion, that together explain over $78 \%$ variance. The first component is mainly composed by the relief ratio, Melton index and watershed length, while the second component is determined by parameters of relief characteristics, area with slope $>25^{\circ}$ and watershed relief.

Though morphometric study itself is not sufficient to explain extensively the occurrence of maximal discharges in the events of destructive torrential floods, morphometric analysis can meaningfully contribute to the explanation of torrential flood events.

\section{Acknowledgement}

This paper is a result of financial support of the Ministry of Education, Science and Technological Develeopment of the Republic of Serbia (authors from Serbia) and the project STSM in the frame of COST Action CA16209 Natural Flood Retention on Private Land (LAND4FLOOD) (author from Bulgaria).

\section{REFERENCES}

[1] Petrović A, Kostadinov S, Dragićević S (2014) The Inventory and Characterization of Torrential Flood Phenomenon in Serbia. Polish Journal of Environmental Studies 23(3): 823-830.

[2] Kostadinov S, Dragićević S, Stefanović T, et al. (2017) Torrential flood prevention in the Kolubara river basin. Journal of Mounain Science 14: 2230-2245. https://doi.org/10.1007/s11629-017-4575-9

[3] Costa JE (1987) Hydraulics and basin morphometry of the largest flash floods in the conterminous United States. Journal of Hydrology 93(3-4): 313-338. https://doi.org/10.1016/0022-1694(87)90102-8

[4] Perucca LP, Angillieri YE (2011) Morphometric characterization of del Molle Basin applied to the evaluation of flash floods hazard, Iglesia Department, San Juan, Argentina. Quaternary International 233(1): 81-86. https://doi.org/10.1016/j.quaint.2010.08.007

[5] Angillieri ME (2012) Morphometric characterization of the Carrizal basin applied to the evaluation of flash floods hazard, San Juan, Argentina. Quaternary International 253: 74-79. https://doi.org/10.1016/j.quaint.2011.05.011

[6] Baltakova A, Nikolova V, Kenderova R, et al. (2018) Analysis of Debris Flows by Application of GIS and Remote Sensing: Case Study of Western Foothills of Pirin Mountain (Bulgaria). In Chernomorets SS et al. (eds.) Proceedings of the 5th International Conference "Debris Flows: disasters, risk, forecast, protection". Publishing House "Universal", Tbilisi, Geogria. pp 22-32.

[7] Charizopoulos N, Mourtzios P, Psilovikos T, et al. (2019) Morphometric analysis of the drainage network of Samos Island (northern Aegean Sea): Insights into tectonic control and flood hazards. Comptes Rendus Geoscience 351 (5): 375-383. https://doi.org/10.1016/j.crte.2019.03.001

[8] Melton MA (1957) An analysis of the relations among elements of climate, surface properties and geomorphology. New York: Columbia University, Technical report No 11. p 102.

[9] Melton MA (1958) Geometric properties of mature drainage basins and their representation in an E4 phase space. The Journal of Geology 66(1): 35-54. 
[10] Benson MA (1964) Factors affecting the occurrence of floods in the southwest. U.S. Geological Survey Water Supply Paper, 1580-D: 72 pp.

[11] Patton PC, Baker VR (1976) Morphometry and floods in small drainage basins subject to diverse hydrogeomorphic controls. Water Resources Research 12 (5): 941-952. https://doi.org/10.1029/WR012i005p00941

[12] Taha MMN, Elbarbary SM, Naguib DM, et al. (2017) Flash flood hazard zonation based on basin morphometry using remote sensing and GIS techniques: A case study of Wadi Qena basin, Eastern Desert, Egypt. Remote Sensing Applications: Society and Environment 8: 157-167. http://dx.doi.org/10.1016/j.rsase.2017.08.007

[13] Khurana D, Rawat SS, Raina G, et al. (2020) GIS-Based Morphometric Analysis and Prioritization of Upper Ravi Catchment, Himachal Pradesh, India. In: AlKhaddar R, et al. (eds.), Advances in Water Resources Engineering and Management. Lecture Notes in Civil Engineering, vol 39. Springer, Singapore. pp 163-185.

[14] Loczy D, Kis E, Schweitzer F (2009) Local flood hazards assessed from channel morphometry along the Tisza River in Hungary. Geomorphology, 113(3-4): 200-209. https://doi.org/10.1016/j.geomorph.2009.03.013

[15] NASA JPL (2014) NASA Shuttle Radar Topography Mission, Swath Image Data [V 003]. NASA EOSDIS Land Processes DAAC

[16] Schumm SA (1956) Evolution of drainage system and slopes in badlands at Perth Ambny, New Jersey. Geological Society of America Bulletin 67 (5): 597-646. https://doi.org/10.1130/0016-7606(1956)67[597:EODSAS]2.0.CO;2

[17] Strahler AN (1958) Dimensional analysis applied to fluvially eroded landforms. Geological Society of America Bulletin 69:279-99. https://doi.org/10.1130/00167606(1958)69[279:DAATFE]2.0.CO;2

[18] Williams F (1992) Reasoning with statistics: How to read quantative research (4th edition). Harcourt Brace Jovanovich College Publishers. p 220

[19] Olkin I, Sampson AR (2001) Multivariate Analysis: Overview. In Smelser NJ et al. (eds), International Encyclopedia of the Social \& Behavioral Sciences. Pergamon, pp 10240-10247. https://doi.org/10.1016/B0-08-043076-7/00472-1

[20] Zeller RA (2005) Measurement Error, Issues and Solutions. In Kempf-Leonard K (ed), Encyclopedia of Social Measurement. Elsevier. pp 665-676. https://doi.org/10.1016/B0-12369398-5/00109-2

[21] Tabachnick BG, Fidell LS (2007) Using multivariate statistics. Boston: Pearson/Allyn \& Bacon. P 983

[22] Avinash K, Jayappa KS, Deepika B (2011) Prioritization of subbasins based on geomorphology and morphometricanalysis using remote sensing and geographic informationsystem (GIS) techniques, Geocarto International 26(7): 569-592. http://dx.doi.org/10.1080/10106049.2011.606925

[23] Gumma MK, Birhanu BZ, Mohammed IA, et al. (2016) Prioritization of Watersheds across Mali Using Remote Sensing Data and GIS Techniques for Agricultural Development Planning. Water 8: 260. https://doi.org/10.3390/w8060260

[24] Puno GR, Puno RCC (2019) Watershed conservation prioritization using geomorphometric and land use-land cover parameters. Global Journal of Environmental Science and Management 5(3): 279-294. https://doi.org/10.22034/gjesm.2019.03.02

[25] Jackson L, Kostaschuk R, MacDonald G (1987) Identification of debris flow hazard on alluvial fans in theCanadian Rocky Mountains. In: Costa JE et al. (eds.), Debris flows/avalanches, vol 7. Geological Society of America. pp 115-124 
[26] Kaiser HF (1974) An index of factorial simplicity. Psychometrika 39: 31-36. https://doi.org/10.1007/BF02291575

[27] Bartlett MS (1954) A Note on the Multiplying Factors for Various Chi Square Approximations. Journal of the Royal Statistical Society 16: 296-298. https://doi.org/10.1111/j.2517-6161.1954.tb00174.x 